\title{
An overview of online marketing promotion activities in the event tourism of the Moravica district
}

\author{
Miloš Papić ${ }^{1}$, Dušan Garabinović ${ }^{2}$, Marija Blagojević ${ }^{1 *}$ \\ ${ }^{1}$ University of Kragujevac, Faculty of Technical Sciences Čačak \\ ${ }^{2}$ Faculty of Business Economics and Entrepreneurship, Belgrade
}

\begin{abstract}
The development of technology in the last few decades has led to major changes in almost all areas of the economy. This is mostly related to production and service delivery processes, but also to other accompanying activities, without which the functioning of business systems is unthinkable today. The Internet is probably one of the most important representatives of this development and a factor without which the modern world can hardly be imagined. Its role is also highlighted in the field of marketing with the emergence of a new concept known as Internet marketing. By linking online marketing and manifestations/events, as one of the most important factors in tourism activity, the basis for satisfying the demands that modern age implies in the process of achieving quality relationships with the target market is created. Events and the way of their presentation, as the basis of marketing communications, with their specificities contribute to the uniqueness of a particular area by creating its image. The aim of this paper was to analyze the degree of the use of the Internet in the marketing activities of local tourist organizations as well as the tourist events of the Moravica administrative district, with particular reference to the use of websites and four most popular social networks.
\end{abstract}

Keywords: online promotion, Internet marketing, social networks, event tourism JEL classification: M31, Z30

\section{Pregled aktivnosti onlajn marketing promocije u manifestacionom turizmu moravičkog okruga}

Sažetak: Razvoj tehnologije u prethodnih nekoliko decenija doveo je do velikih promena u gotovo svim oblastima privrede. Ovo se najviše odnosi na procese proizvodnje i pružanja usluga ali i na druge prateće aktivnostima bez kojih je funkcionisanje poslovnih sistema danas nezamislivo. Internet je verovatno jedan od najznačajnijih predstavnika tog razvoja i činilac bez koga se savremeni svet teško može zamisliti. Njegova uloga se ističe i u oblasti marketinga, sa nastankom novog koncepta poznatog kao Internet marketing. Povezivanjem online marketinga i manifestacija, kao jednih od najznačajnijih činilaca turističke delatnosti, stvara se osnov za zadovoljavanje zahteva koje moderno doba nameće u procesu ostvarivanja kvalitetnih odnosa sa ciljnim tržištem. Manifestacije i način njihovog predstavljanja, kao osnov marketing komunikacija, svojim specifičnostima doprinose jedinstvenosti određenog područja kreirajući njegov imidž. Cilj ovog rada je da analizira stepen korišćenja Interneta u marketing aktivnostima lokalnih turističkih organizacija, kao i turističkih manifestacija Moravičkog upravnog okruga, sa posebnim osvrtom na korišćenje veb sajtova i najpopularnijih društvenih mreža. 
Ključne reči: online promocija, Internet marketing, društvene mreže, manifestacioni turizam JEL klasifikacija: M31, Z30

\section{Introduction}

Tourism can be observed as one of the most important elements in achieving economic growth and development, especially in certain regions and countries that have recognized their potentials in this area in time. The only question is whether somebody (an individual, organization, government, etc.) is ready to realistically perceive current state and situation, finding even minimal specificity that could distinguish them from the others and that could be the base for its market offer. It can be many things, a diverse dice combination that makes the overall mosaic of tourist offer.

Different kinds of events (cultural, music, sports, gastronomy, festivals, etc.) are listed as a tourism product of special importance for tourism development according to the Tourism Development Strategy of the Republic of Serbia for 2016-2025 period (The Government of Republic of Serbia, Ministry of Trade, Tourism and Telecommunications, 2016, p. 28). They are also mentioned as direct effects of tourism (The Government of Serbia, Ministry of Trade, Tourism and Telecommunications, 2016, p. 42). That way, events are, at the same time, one of the crucial initiators of the overall tourism activity, but also one of the main results of its development. Global trends, the so-called megatrends, also have influence on events development and tourism in general (Senić \& Manojlović, 2017).

"Conceptually speaking, tourism events, tourist shows, performances and festivals mark periods of performing programs with certain content that is attractive for tourist visits." (Bjeljac, 2006, p. 7).

Events should be presented in a right way so that the target audience gets interested. Marketing activities are inevitable in this domain. Garabinovic (2017) states that marketing in tourism is related to various types of companies from tourism area that try to achieve goals they set in order to be satisfied with the realization of the planned profit and also in order to satisfy the tourists.

\section{Event tourism}

Event tourism plays a key role in building a more attractive destination. Significant motivator for tourism and development of destinations' marketing are tourism events. According to Getz $(2008$, p. 404) "Planned events are spatial-temporal phenomenon, and each is unique because of interactions among the setting, people and management systems including design elements and the program". The same author concluded that events are very important and they could satisfy many strategic goals. This is the reason for non-letting this job to amateurs.

According to Getz and Page (2016) all events and venues have its own topology, which is presented in Figure 1. Same authors pointed out that all events could be categorized into four categories: business, festivals and cultures, entertainment and sports. 
Figure 1: Typology of planned events and venues

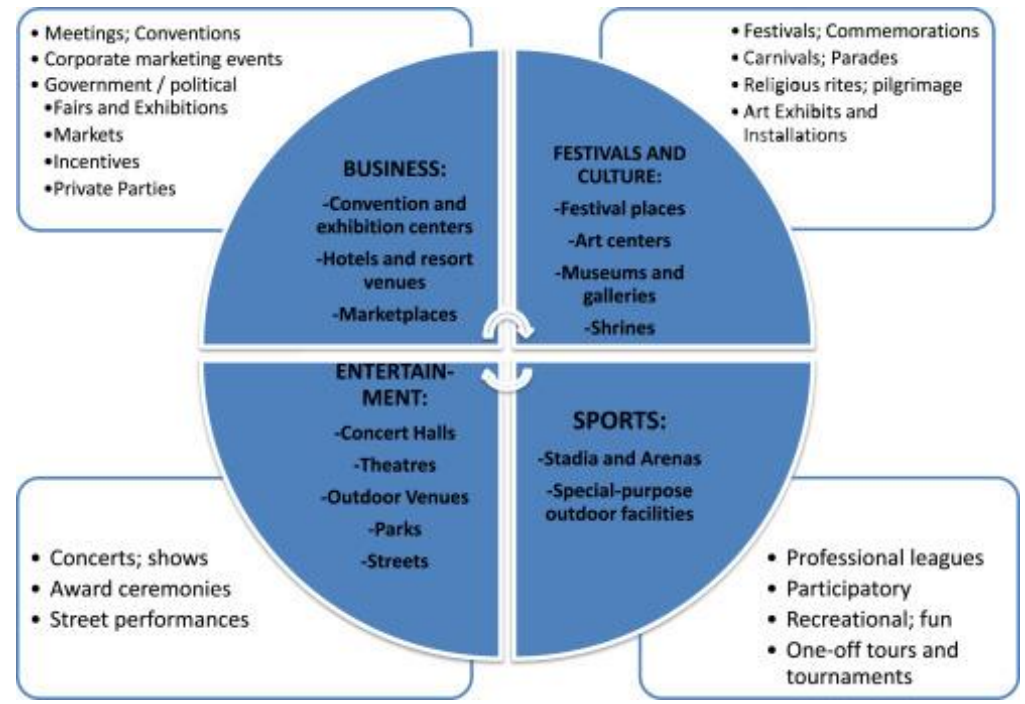

Source: Getz \& Page (2016)

\section{Internet promotion as part of modern marketing}

Depending on the need for information, tourist marketers have to adapt their strategies for informing the target market. Đorđević (2013) conducted research in this domain and concluded that segmentation based on the importance of diverse types of information for tourists in decision making on travel is statistically more efficient than the one based on traditional criteria. He (Djordjević 2013, p. 83) also concludes that special focus has to be placed on the segment of tourists that need information about destination, hotels and travel programs, as well as the segment of tourists that value information about different brands.

Maric et al. (2017) analyzed the position and role of the modern customer in virtual space, i.e., in electronic interpersonal communication processes. They state that in regard to the traditional marketing environment, the biggest changes that generate the current marketing environment of the company are related to a technological dimension, i.e. electronic environment with the new role of the customers on the market and in the society as the consequence. They particularly emphasize the role of the Internet in these processes, putting greater emphasis on strengthening the negotiating power of the consumers themselves. Analyzing social networks, they state that the main motivation to join them is the possibility of social influence on others and the desire to belong to a particular group (Marić et al., 2017, p. 149).

Oklobdžija and Popesku (2017) analyzed a connection between digital media and making decisions about travel, with the focus on the impact of the IT on tourism activity, especially through the Web 2.0, Web 3.0 and Tourism 2.0 that occurs under their constant development. In their work, they presented the results of the research conducted from March 30 to April 15,2016 , on the total number of 444 respondents, in which $66.67 \%$ of the respondents stated that the main source of information for the selection of the tourist destination is digital media, especially for persons under 40 years old. When it comes to specific types of digital media, the results showed that the most commonly used are Internet searches $(75.70 \%)$, followed by official websites of tourist destinations $(51.60 \%)$, recommendations of other tourists $(33.50 \%)$, social media $(17.90 \%)$ and promotional materials received via email $(8.10 \%)$. 
According to a research conducted by the Tourist Organization of Serbia and ProPozitiv (Agency for Market and Public Opinion Research) about the opinions and habits of domestic tourists in Serbia in 2015 (Tourist Organization of Serbia, etc.), the most frequently used websites as the source of information about the tourist destination are websites of local tourist organizations and websites that promote the local tourist destination (40\%), followed by websites for hospitality and other accommodation facilities (20\%), social networks (Facebook) (19\%), tourism specialized websites (18\%), websites not specialized in tourism $(15 \%)$, Internet tourism forums (12\%), tourist agency websites (12\%) and Internet blogs on tourism $(2 \%)$.

A special review of social networks, as one of the most influential parts of Internet marketing, and their role in marketing communication was made by Tomše and Snoj (2014). They observed main differences between traditional and marketing communications on social networks and their advantages and disadvantages in times of crisis. Among the positive aspects, the ones which were highlighted are: possibility of applying different advertising options, paid (such as banners, sponsored links, etc.), as well as completely free options - Facebook and Twitter accounts, writing blogs and/or participating in other authors' blogs, participating in forums, posting videos on YouTube, etc.

Authors of this research will try to summarize all relevant data which is available online about event tourism in Moravica district. The specific goal will be the analysis of Internet usage in marketing activities of event tourism i.e. the existence of websites and accounts/profiles/channels on most popular social networks.

\section{Conceptual and territorial determination of the Moravica Administrative District}

Moravica Administrative District (defined in 2006 by Decree on Administrative Districts (Official Gazette of the Republic of Serbia No. 15/06)) includes four local administrations Čačak, Lučani, Gornji Milanovac and Ivanjica, of which only Čačak has the status of a city, and as such represents its administrative center. The characteristic is the spatial distribution of the district that goes north to south in the way that every local administration is located right next to previous, starting from Gornji Milanovac on the north, followed by Čačak and Lučani and to Ivanjica on the south. It borders with four districts - Kolubara, Šumadija, Raška and Zlatibor. The total area covered by the Moravica Administrative District is about $3016 \mathrm{~km} 2$ (Moravica Administrative District), with the largest share in the municipality of Ivanjica (36.14\%), followed by the municipality of Gornji Milanovac $(27.72 \%)$, the city of Čačak (21.09\%), while the smallest territory has the municipality of Lučani (15.05\%). When it comes to the population (212 603 according to the 2011 census), the situation is somewhat different. The most dominant in the structure of the population is the city of Čačak $(54.25 \%)$, followed by the municipality of Gornji Milanovac (20.89\%), Ivanjica (15.03\%) and the least, as well as the territory, the municipality of Lučani $(9.83 \%)$.

The rich tourist offer of the Moravica Administrative District is additionally complemented by numerous events held on its territory. Of course, some events have local or regional character, and they are not so familiar to people living in other parts of Serbia, but there are also those that are well known not only in Serbia but also in the surrounding area. The diverse themes of the events and accompanying activities make each event stand out in its particularity, matching with the colorful ambience of the overall tourist offer of the district. This rich tourist offer represents a great potential for the development of the economy of this area. The existence of tourist organizations at the local level has the task of discovering new and promoting tourism potentials so that more people are interested in visiting them. Therefore, tourist organizations are useful for the society, primarily in the economy. 


\section{Organization of the research}

As we saw, the combination of the Internet, marketing and tourism forms the basis of a modern approach to the formation of a market offer and its communication to the target market. That is exactly what will be the focus of this paper, primarily focusing on the position of online marketing in the tourist sector of the Moravica Administrative District tourist organizations and events. Actually, we will analyze the activities of online promotion of tourist events that take place on the territory of the Moravica Administrative District. We will determine whether and to what extent these events use the most known social networks (Facebook, Twitter, Instagram and YouTube) and whether they have a website or possibly a blog.

Given that the number of followers, likes and posts changes on a daily basis, it is important to note that the whole research was conducted from $22^{\text {nd }}$ to $25^{\text {th }}$ of February, 2018.

It is a known fact that each of the four local administrations in Moravica district has its own tourist organization. At the start of our research, we searched the Internet to be sure that all tourist organizations have their websites. After that, by analyzing data on the events taking place on the territory of the Moravica District based on the websites of the tourist organizations, it became known that there are 98 events (64 in Čačak, 22 in Gornji Milanovac, 6 in Lučani and 6 in Ivanjica). These events were marked by local tourist organizations as the most important ones and they represent the research sample in this paper. The second part of our research was to examine for each of 98 events whether it has a website, an account/profile on Facebook, Twitter and Instagram or a channel on YouTube.

\section{Results and discussion}

Table 1 summarizes the analysis of presence/activity of tourist organizations from the Moravica district on the Internet i.e. analyzed social networks.

Table 1: Websites and social network accounts of tourist organizations

\begin{tabular}{|l|c|c|c|c|c|}
\hline Tourist Organization & Website & Facebook & Twitter & Instagram & YouTube \\
\hline Čačak & + & + & + & & + \\
\hline Lučani & + & + & + & + & + \\
\hline Gornji Milanovac & + & + & + & & + \\
\hline Ivanjica & + & + & + & & \\
\hline
\end{tabular}

Source: Authors - the research conducted on February 22, 2018

Based on the collected data, it can be seen that all four tourist organizations have their own website, that Facebook and Twitter are the most popular among social networks since all organizations have accounts on them. Instagram is used by only one organization, while three of them have official YouTube channels.

Following the table, the events which use some of the analyzed elements of Internet marketing are presented. 
Table 2: Tourist events of Moravica district that use some of the analyzed forms of Internet marketing

\begin{tabular}{|c|c|c|c|c|c|c|c|}
\hline No. & Name & Place & Website & Facebook & Twitter & Instagram & YouTube \\
\hline 1. & Animanima & Čačak & + & + & & & \\
\hline 2. & Karusel & Čačak & + & + & & & + \\
\hline 3. & Kupusijada & Čačak & + & + & & + & \\
\hline 4. & $\begin{array}{l}\text { Summer days of } \\
\text { culture }\end{array}$ & Čačak & & + & & & \\
\hline 5. & $\begin{array}{l}\text { International poetry } \\
\text { meetings of Mrčajevci }\end{array}$ & Čačak & & + & & & \\
\hline 6. & $\begin{array}{l}\text { Pasuljijada "Ljubićski } \\
\text { kotlić" }\end{array}$ & Čačak & & + & & & \\
\hline 7. & \begin{tabular}{|l|} 
Fruits of the Western \\
Pomoravlje
\end{tabular} & Čačak & & + & & & \\
\hline 8. & Preljina expo & Čačak & & + & & & \\
\hline 9. & \begin{tabular}{|l} 
Flute festival of \\
Serbia "Oj, Moravo"
\end{tabular} & Čačak & & + & & & \\
\hline 10. & Art and paper & Čačak & & + & & & \\
\hline 11. & $\begin{array}{l}\text { Dragačevo Trumpet } \\
\text { Festival }\end{array}$ & Lučani & + & + & + & + & \\
\hline 12. & Rock'n'Roll Sabor & Lučani & & + & & & + \\
\hline 13. & $\begin{array}{l}\text { Short form "Short and } \\
\text { Mini Film Festival" }\end{array}$ & \begin{tabular}{|l|} 
Gornji \\
Milanovac
\end{tabular} & + & + & & + & \\
\hline 14. & Rakijada & \begin{tabular}{|l|} 
Gornji \\
Milanovac \\
\end{tabular} & & + & + & + & \\
\hline 15. & $\begin{array}{l}\text { Serbia Festival of the } \\
\text { World Music }\end{array}$ & \begin{tabular}{|l|} 
Gornji \\
Milanovac \\
\end{tabular} & + & + & + & & + \\
\hline 16. & Šilopaj's Panorama & \begin{tabular}{|l} 
Gornji \\
Milanovac
\end{tabular} & & + & & & \\
\hline 17. & $\begin{array}{l}\text { Festival of Traditional } \\
\text { Serbian Songs }\end{array}$ & Ivanjica & & + & & & \\
\hline 18. & Nušićijada & Ivanjica & + & + & + & + & + \\
\hline
\end{tabular}

Source: Authors - the research conducted from $22^{\text {nd }}$ to $25^{\text {th }}$ of February, 2018.

When it comes to using websites as official presentations, only 7 out of 98 events $(7.14 \%)$ have their own website. Out of that number, 3 sites have a version in only one language (Serbian), while the other 4 have versions in two languages.

The usage of Facebook is presented in Figure 2. It is used by 18 events (18.37\%). The average number of followers is 1 486. 5 pages have more than 1000 followers, and the largest number is 10412 (Nušićijada). When it comes to the number of likes, the average number is 1492.5 pages have more than 1000 - the same event as the number of followers. The Facebook page of Nušićijada stands out with the highest number of likes (10 441). 
Figure 2: The usage of Facebook (number of likes and followers)

Dragacevo Trumpet Festival

R'n'R Festival

Festival of Traditional Serbian Songs 'Prilike'

Nusicijada

Serbian World Music Festival

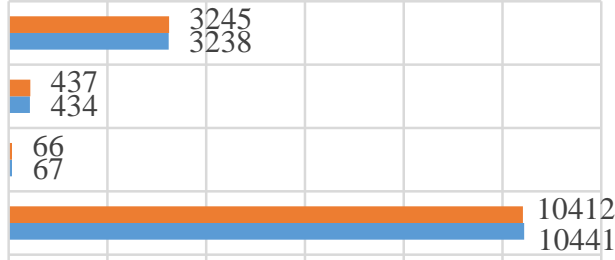

$$
\begin{array}{r}
\text { Rakijada } \\
\text { Panorama of Silopaj }
\end{array}
$$

Short form, International Short Film Festival

Ljubic's kettle, Pasuljijada

Art and paper

Summer days of culture in Cacak

Karusel

Serbian Pipe Player Festival 'Oj, Moravo'

The fruits of the Western Morava valley

Animanima

Kupusijada

Preljina expo

International poetry meetings in Mrcajevci

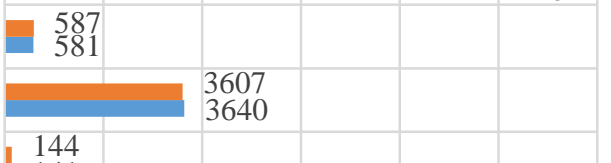

\begin{tabular}{l}
144 \\
141 \\
\hline
\end{tabular}

789
782

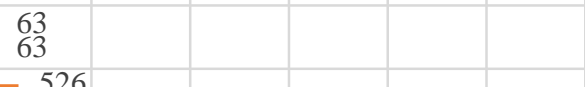

526

203
206

1075
1103

385
380

147
147

813

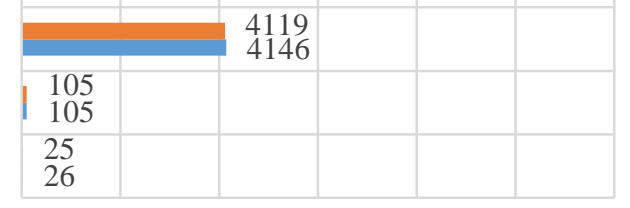

0

$2000 \quad 4000 \quad 6000 \quad 8000 \quad 10000 \quad 12000$

Number (followers/likes)

Followers Likes

Source: Authors - the research conducted from $22^{\text {nd }}$ to $25^{\text {th }}$ of February, 2018.

Four events $(4.08 \%$ ) are using Twitter (Figure 3), with the average number of tweets of 155 and followers of 148. As regards both of the above criteria (as with Facebook), the Twitter account of Nušićijada (359 tweets, 329 followers) stands out. 
Figure 3: The usage of Twitter (number of followers and tweets)

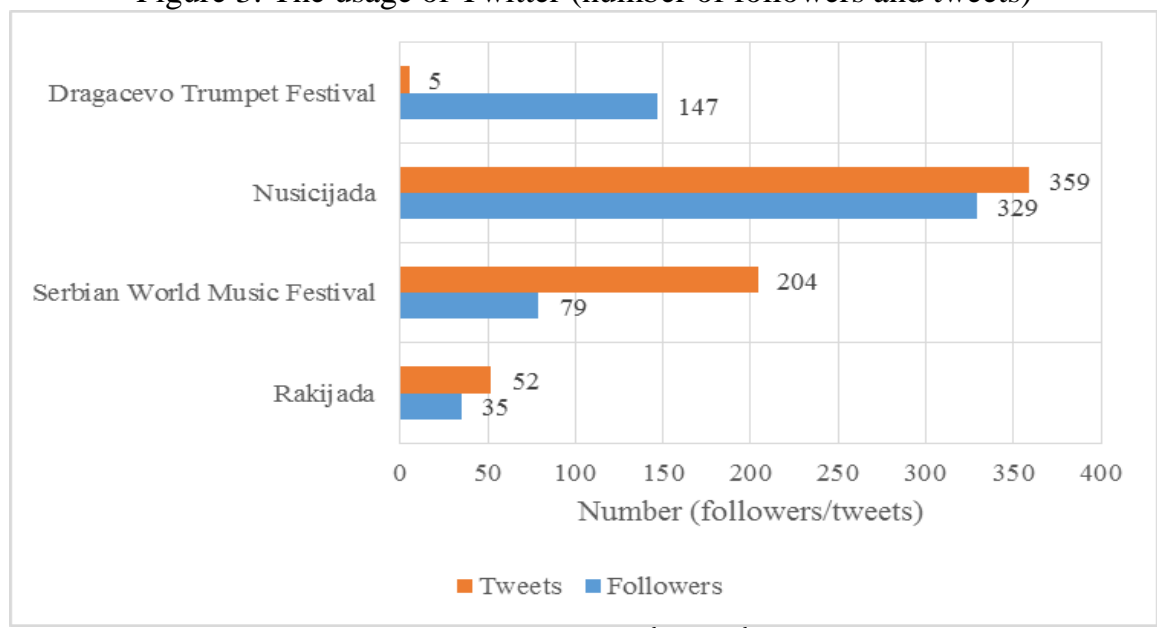

Source: Authors - the research conducted from $22^{\text {nd }}$ to $25^{\text {th }}$ of February, 2018.

Only 5 events $(5.10 \%)$ have their own Instagram account (figure 4) with the average number of 56 posts and 294 followers. The most posts (237) and followers (1073) has Nušićijada.

Figure 4: The usage of Instagram (numbers of followers and posts)

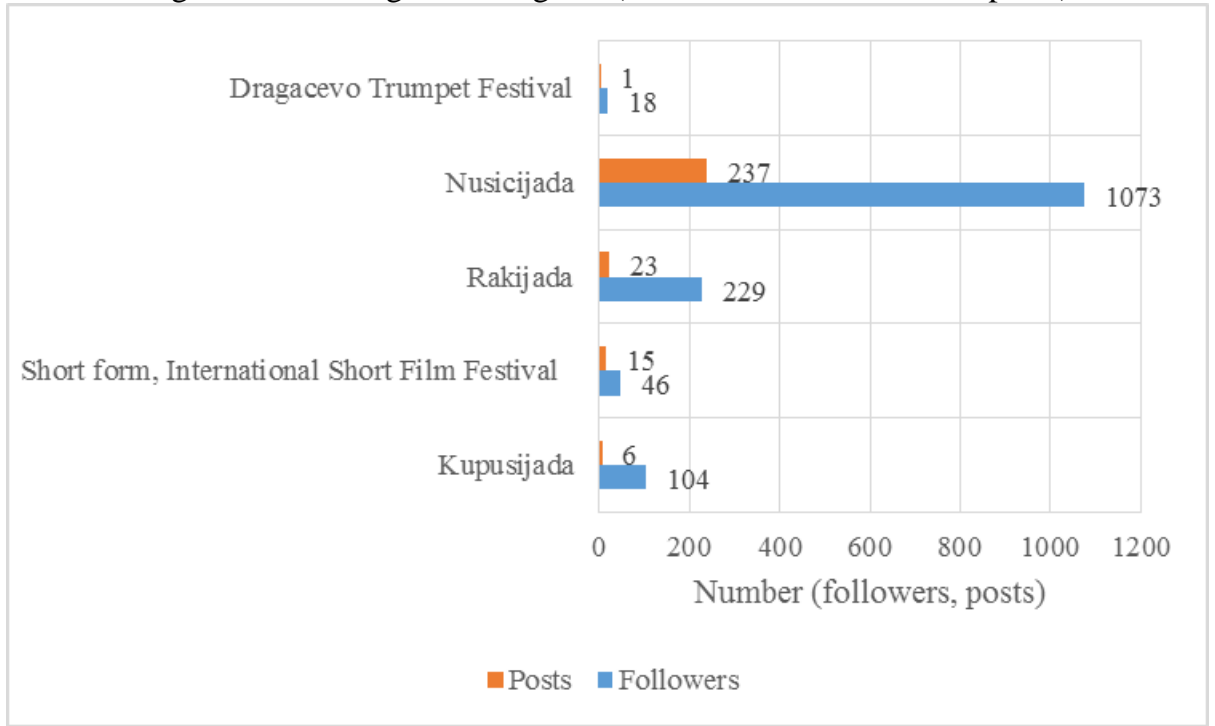

Source: Authors - the research conducted from $22^{\text {nd }}$ to $25^{\text {th }}$ of February, 2018.

Only 4 events $(4.08 \%)$ have official YouTube channels (Figure 5), with average number of 54 uploaded videos and 42 followers. The average number of views (based on one video per channel with the maximum number of views) is 6150 . In all three categories (number of posts - 103, followers - 78 and most viewed videos - 12 479) YouTube channel of Karusel festival is dominant. 
Figure 5: The usage of YouTube (views, followers and posts)

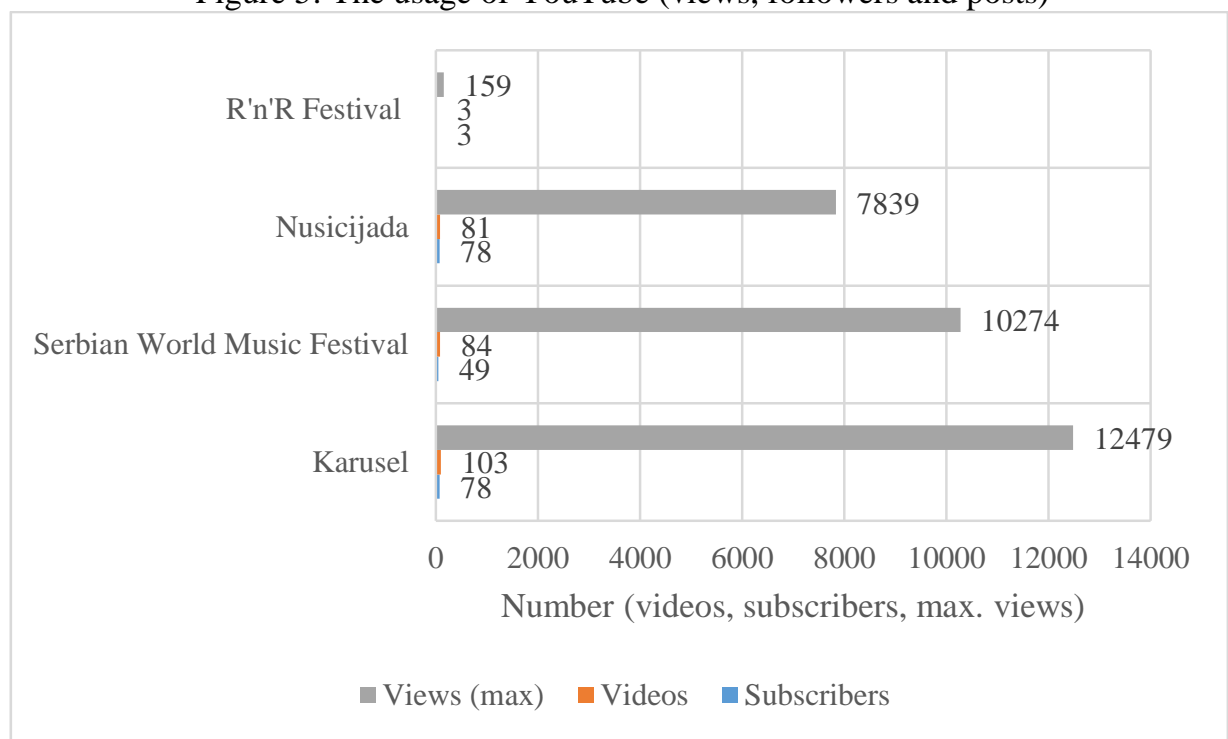

Source: Authors - the research conducted from $22^{\text {nd }}$ to $25^{\text {th }}$ of February, 2018.

In the following figure (Figure 6), you can see a summary overview of using websites, social networks, and YouTube, where data on the secondary y axis is expressed in percentages.

Figure 6: Overview of the use of analyzed social networks and websites

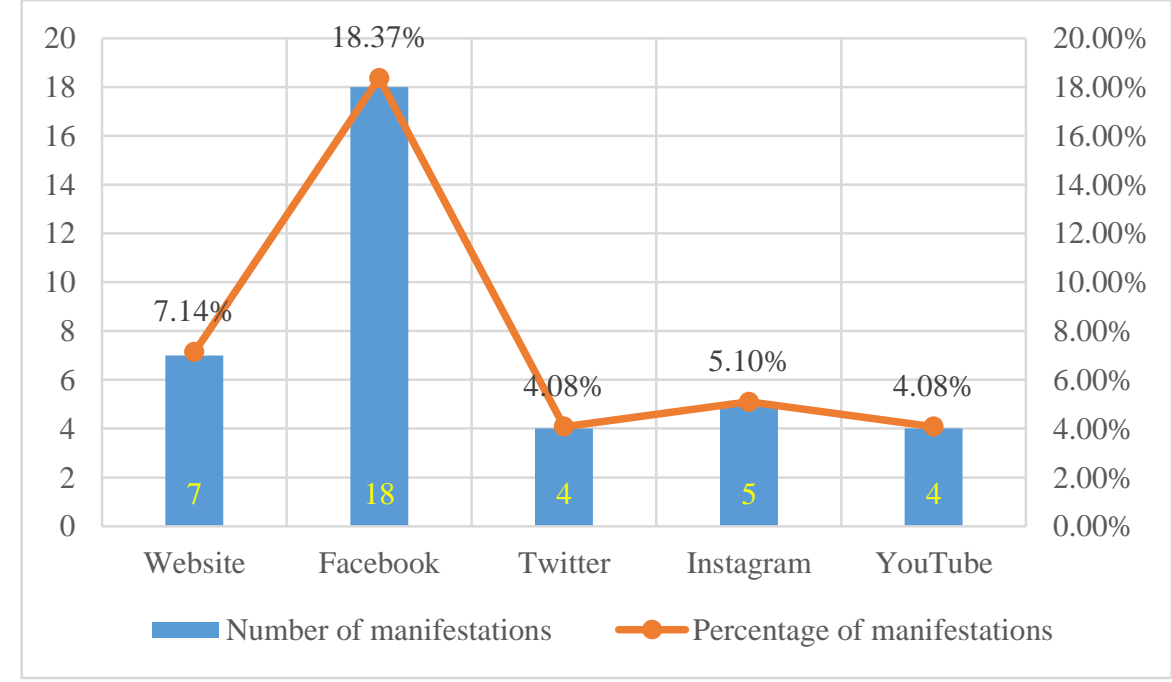

Source: Authors - research conducted from $22^{\text {nd }}$ to $25^{\text {th }}$ of February, 2018.

According to Figure 6, most events use Facebook, which is generally also most popular social network, as their promoting tool (18.37\%). At the second place is a website usage, and then Instagram, Twiter and Youtube follow. Only one event (1.02\%, Nušićijada) uses all five analyzed resources, two of them $(2.04 \%)$ use 4 , four events $(4.08 \%)$ use 3 , two events $(2.04 \%)$ use 2, and nine events $(9.18 \%)$ use 1 resource and that is Facebook. As opposed to this, 80 events $(81.36 \%)$ do not have any element which indicates their online activity nor even visibility. 


\section{Conclusion}

In this paper, we wanted to point out the importance of online promotion as an integral part of marketing in the field of tourism. We analyzed 98 well-known tourist events/events that take place in the territory of the Moravica Administrative District and we came to the results that the application of the Internet services is very limited in the promotion activities:

- Only 7 out of 98 events (7.14\%) have websites. Out of that number, 3 web pages have a version only in one language (Serbian), while other 4 have bilingual versions;

- Facebook used by 18 events (18.37\%). Facebook page of Nušićijada stands out with the largest number of likes (10 441) and followers (10 412);

- 4 events use Twitter (4.08\%). As with Facebook, Twitter account of Nušićijada stands out;

- 5 events have their own Instagram accounts (5.10\%). The largest number of posts (237) and followers (1 073) has Nušićijada.

- 4 events $(4.08 \%)$ have official YouTube channels. In all three categories (number of posts - 103, followers - 78 and most viewed videos - 12 479) dominates the YouTube channel of Karusel festival.

- 80 events $(81.36 \%)$ do not have neither their own website nor accounts/channels on social networks Facebook, Twitter, Instagram and YouTube.

Based on the above, we consider that the activity of online promotion of the observed tourist events is represented in the amount far less than expected. Obviously, there is a need for further improvements because tourists and generally people who would potenatially visit some of the events are accustomed to finding everything on the Internet - if there is nothing on the Internet, it is as it does not exist.

Nušićijada (Ivanjica) is the only event that stands out because it is active on all social networks and, in our opinion, has a very high-quality website. It also has its own up to date Android application. As for the YouTube, Nušićijada is in the third place and the first two events (Karusel - Čačak and the Serbian Festival of the World Music - Gornji Milanovac) are of a musical type and are very serious with a clear target audience, and therefore their position from the aspect of this Internet service is not a surprise. We should also mention the International Animation Festival "Animanima", which, in addition to the official website (in two languages) and a Facebook page, also uses Vimeo (a site like YouTube) and Issuu (digital magazine). Dragačevo Trumpet Festival in Guča (Lučani) is probably the most famous event in Moravica district but it does not have a YouTube channel which is a surprise.

Given that now the question can be posed as to why the current situation is, we will continue to work on attempts to reach an answer in the future. The directions of further research will relate to the analysis of the time required to maintain accounts on social networks and on the website also. We will also analyze how many perpetrators are needed for such a job, how much is a monthly fee or a working hour for these jobs, and whether there are officially defined jobs for this purpose; what level of education is needed and what completed schools would be a prerequisite for this job to be done professionally.

Practical implications of the research refer to the effects that resulted from the researched subjects. In this research, the results show an immediate need for more marketing activity in the area of event tourism. The use of all the analyzed social networks is basically free, and nowadays, a large percentage of people own smartphones and other devices connected to the Internet, so our conclusion is that this state of affairs for modern business conditions is inadequate.

Limitations of this research are related to the district that we analyzed. For more precise and adequate analysis, we have to include other districts. 


\section{References}

1. Bjeljac, Ž. (2006). Teorijsko-metodološke osnove manifestacionog turizma [Theoretical and methodological basics of manifestation tourism]. Beograd: Srpska akademija nauka i umetnosti, Geografski institut „Jovan Cvijić“.

2. Getz, D. (2008). Event tourism: Definition, evolution, and research. Tourism Management, 29, 403-428. https://doi.org/10.1016/j.tourman.2007.07.017

3. Getz, D. \& Page, S. (2016). Progress and prospects for event tourism research. Tourism Management, 52, 593-631. https://doi.org/10.1016/j.tourman.2015.03.007

4. Đorđević, A. (2013). Značaj informacija za korisnike turističkih usluga u odlučivanju o putovanju [The importance of information for travel services users in travel decision making]. Marketing: časopis za marketing teoriju i praksu, 44 (1), 75-85.

5. Garabinović, D. (2017). Menadžment marketinga u turizmu [Marketing Management in Tourism]. U M. Krstić (ured.), Zbornik radova Prva nacionalna naučno-stručna konferencija sa međunarodnim učešćem „,Trendovi u poslovanju 2017“ (pp. 313324). Kruševac: Visoka poslovna škola strukovnih studija „Prof. dr Radomir Bojković“".

6. Marić, D., Kovač Žnideršić, R., Paskaš, N., Jevtić, J. \& Kanjuga, Z. (2017). Savremeni potrošač i elektronska interpersonalna komunikacija [Modern consumer and electronic interpersonal communication]. Marketing: časopis za marketing teoriju i praksu, 48(3), 147-154.

7. Moravički upravni okrug [Moravica Administrative District]. Retrieved April 18, 2018 from http://moravickiupravniokrug.org/

8. Oklobdžija, S. \& Popesku J. (2017). The Link Between Digital Media and Making Travel Choices. Marketing: časopis za marketing teoriju i praksu, 48(2), 75-85.

9. Senić, V. \& Manojlović, N. (2017). Savremene tendencije u turizmu [Modern tendencies in tourism]. Menadžment $u$ hotelijerstvu i turizmu, 5(1), 18-27. Retrieved May 28, 2018 from:

http://hit-vb.kg.ac.rs/htmanagement/index.php/HITM/article/view/23

10. The Government of Serbia, Ministry of Trade, Tourism and Telecommunications. Retrieved May 28, 2018 from http://mtt.gov.rs/

11. Tomše, D. \& Snoj, B. (2014). Marketing Communication on Social Networks Solution in the Times of Crisis. Marketing: časopis za marketing teoriju i praksu, 45(2), 131-138.

12. Turistička organizacija Čačka [Tourist organization od Čačak]. Retrieved April 18, 2018 from http://turizamcacak.org.rs/o-nama/ju-toc/

13. Turistička organizacija opštine Gornji Milanovac [Tourist organization of Gornji Milanovac]. Retrieved April 18, 2018 from http://www.togm.org.rs/

14. Turistička organizacija Srbije i ProPozitiv [Tourist organization of Serbia and Propozitiv] (agencija za istraživanje tržišta i javnog mnjenja) (n.d.). Stavovi $i$ navike domaćih turista $u$ Srbiji 2015. Retrieved April 18, 2018 from http://www.srbija.travel/upload/documents/ProPozitiv\%20i\%20TOS\%20prezentacija \%20istrazivanja\%20FINAL.pdf

15. Vlada Republike Srbije, Ministarstvo trgovine, turizma i telekomunikacija [The Government of Republic of Serbia, Ministry of Trade, Tourism and Telecommunications], Strategija razvoja turizma Republike Srbije za period 2016. 2025. Retrieved April 18, 2018 from http://mtt.gov.rs/download/3/strategija.pdf

Received: 15 May 2018; Sent for revision: 28 May 2018; Accepted: 6 June 2018 